Archive for

Organic Chemistry

Arkivoc 2018, part ii, 81-89

\title{
Brønsted acid-catalyzed metal-free one-pot synthesis of benzimidazoles via [4+1] heteroannulation of ortho-phenylenediamines with $\beta$-oxodithioesters
}

\author{
Abhijeet Srivastava, Gaurav Shukla, Dhananjay Yadav, and Maya Shankar Singh* \\ Department of Chemistry, Institute of Science, Banaras Hindu University, Varanasi-221005, India \\ Email: mayashankarbhu@gmail.com
}

\section{Dedicated to Professor Kenneth K. Laali in honor of his 65th anniversary}

Received 02-21-2017

Accepted 08-27-2017

Published on line $10-29-2017$

\section{Abstract}

An operationally simple and user-friendly one-pot domino protocol for the synthesis of 2-aryl/hetaryl benzimidazoles has been devised from easily available and inexpensive 1,2-phenylenediamines and $\beta$ oxodithioesters. The strategic [4+1] heteroannulation initiated by Brønsted acid PTSA relies on remarkable domino sequence of condensation, cyclization, and elimination. The current approach enables $\mathrm{N}-\mathrm{H} / \mathrm{N}-\mathrm{H}$ functionalization under solventless and metal-free conditions leading to diverse benzimidazoles. The reactions proceeded smoothly affording the desired products in good to excellent yields, exhibiting gram-scale ability and broad functional groups tolerance. Notably, the approach is highly chemo- and regioselective.

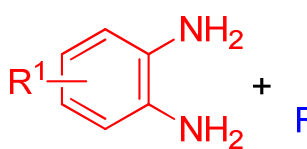

1

$\mathrm{R}^{1}=\mathrm{H}, 4-\mathrm{Me}, 4-\mathrm{Cl}, 4-\mathrm{Br}$

$\mathrm{R}^{2}=$ aryl, hetaryl

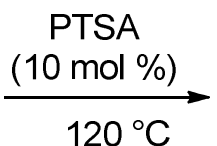

no external metal open air, 8-14 h<smiles>[R]c1cc2[nH][R1](C=[R])cc2n1</smiles>

3

14 examples

$70-92 \%$ yields

- new bonds

\# cascade C-N/C-N bonds formation \# totally site selective

\# operationally simple \# no external metal

\# wide functional group tolerance \# solventless condition

Keywords: $\beta$-oxodithioesters, 1,2-phenylenediamines, $p$-toluenesulfonic acid (PTSA), heteroannulation, benzimidazoles, metal-free, solventless conditions 


\section{Introduction}

The benzofused nitrogen heterocycles have a great importance in drug discovery and materials, among them benzimidazole scaffold is of particular interest and has been categorized as a privileged scaffold. ${ }^{1}$ Several benzimidazole derivatives exhibit diversified pharmaceutical properties such as antimicrobial, ${ }^{2}$ anticancer, ${ }^{3}$ antiviral, ${ }^{4}$ antihelmintic, ${ }^{5}$ antioxidant, ${ }^{6}$ antiulcer, ${ }^{7}$ antihypertensive ${ }^{8}$ and antitubercular. ${ }^{9}$ In addition, benzimidazoles have also been utilized as ligands for transition metals in model biological systems. ${ }^{10}$ They were also found to be useful in dyes, ${ }^{11}$ chemosensing, ${ }^{12}$ fluorescence, and corrosion science. ${ }^{13}$

Owing to the vast importance of benzimidazoles in drug discovery and other fields, enormous efforts have been made to develop the operationally simple and efficient synthetic methods for their construction. ${ }^{14-22}$ Classical approaches to benzimidazoles derivatives involve coupling of 1,2-phenylenediamines with aldehydes/carboxylic acids/nitriles/ortho-esters and their derivatives under varying conditions. ${ }^{23-25}$ Modern synthetic methods include efficient $\mathrm{Cu}$-catalyzed amination of $\mathrm{N}$-aryl imines, ${ }^{26}$ elemental sulfur (as traceless oxidizing agent) enabled solvent- and catalyst-free synthesis from alkyl amines and $o$-aminoanilines, ${ }^{27} \mathrm{Na}_{2} \mathrm{~S}$ $\mathrm{FeCl}_{3}$ promoted unbalanced redox condensation reaction between $o$-nitroanilines and alcohols, ${ }^{28}$ solvent-free cobalt- or iron-catalyzed redox condensation of 2-nitroanilines and benzylamines via benzylamine oxidation, nitro reduction, condensation, and aromatization, ${ }^{29}$ Brønsted acid-catalyzed cyclization reactions of 2aminoanilines with $\beta$-diketones under oxidant- and metal-free conditions, ${ }^{30}$ reaction of $o$-substituted anilines with functionalized orthoesters, ${ }^{31} \mathrm{BF}_{3} . \mathrm{Et}_{2} \mathrm{O}$ promoted cyclodehydration of mono- and diacylated product of corresponding 1,2-phenylenediamines and an acyl chloride. ${ }^{32}$

\section{Results and Discussion}

In continuation of our research interests toward the synthetic utility of $\beta$-oxodithioesters, ${ }^{33-41}$ in order to access diverse structurally challenging heterocycles via one-pot solvent-free synthetic protocols, we report herein an operationally simple and straightforward synthesis of benzimidazoles via one-pot domino reaction involving a sequence of imine formation/ $\mathrm{N}$-cyclization/C-C bond cleavage cascade in good to excellent yields (Scheme 1). To the best of our knowledge, there is no report for the synthesis of 2-substituted benzimidazoles directly from $\beta$-oxodithioesters under solventless metal-free conditions.

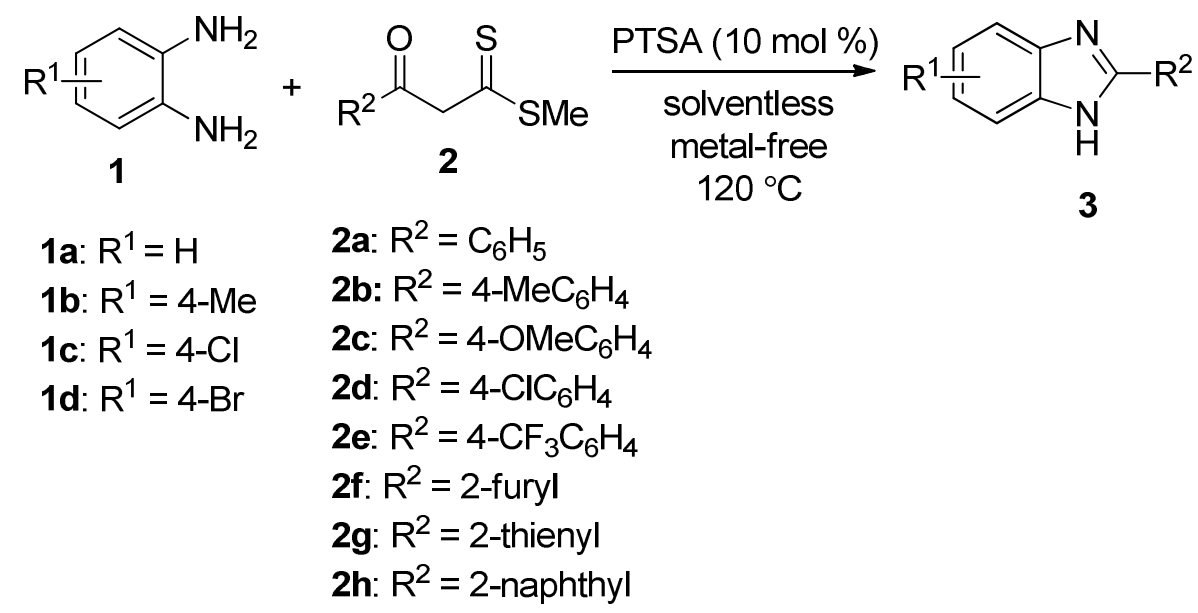

Scheme 1. PTSA-catalyzed one-pot synthesis of benzimidazoles 3. 
Benzimidazoles 3 have been synthesized in one-pot via the reaction of 1,2-phenylenediamines 1 with $\beta$ oxodithioesters 2. Initially, in order to optimize the reaction conditions, 4-methyl-1,2-phenylenediamine (1) and methyl 3-oxo-3-phenylpropanedithioate (2a) have been chosen as model substrates. We performed the model reaction under varying conditions, and the results are listed in Table 1 . On the basis of our previous report, in this study we concentrated on the optimization of catalyst loading, solvent and temperature only. The reaction of $\mathbf{1 b}$ with $\mathbf{2 a}$ in $0.2 \mathrm{~mL}$ of toluene in the presence of $10 \mathrm{~mol} \%$ of PTSA at $90{ }^{\circ} \mathrm{C}$ gave the desired product $3 \mathrm{ba}$ in $40 \%$ yield, (Table 1 , entry 1). Increasing the amount of solvent to $1.0 \mathrm{~mL}$ at the same temperature could not provide better result (Table 1, entry 2). To see the effect of temperature on model reaction, the reaction was performed in the same solvent at reflux temperature. Work up of the reaction afforded the desired product 3 ba in $51 \%$ yield within $12 \mathrm{~h}$ (Table 1, entry 3). Observing the positive effect of temperature on the reaction, next we performed the reaction at $120{ }^{\circ} \mathrm{C}$. To our great satisfaction, the yield of the desired product 3 ba increased to $79 \%$ within $10 \mathrm{~h}$ (Table 1, entry 4). Further reaction at higher temperatures provided the complex TLC pattern and decreased the yield of the desired product, which could be due to decomposition of starting substrates at higher temperatures (Table 1, entries 5 and 6). Finally, we optimized the catalyst loading, and it was found that decreasing the amount of catalyst loading to 5 mol \% lowered the yield, whereas increasing the catalyst loading to $20 \mathrm{~mol} \%$ could not provide the better result (Table 1, entries 7 and 8). Thus, the best reaction conditions for the formation of $\mathbf{3 b a}$ was found to be $\mathbf{1 b}$ (0.5 $\mathrm{mmol}), 2 \mathrm{a}(0.5 \mathrm{mmol})$, PTSA $(10 \mathrm{~mol} \%)$, toluene $(0.2 \mathrm{~mL})$ at $120^{\circ} \mathrm{C}$ in open atmosphere (Table 1 , entry 4$)$.

Table 1. Optimization of reaction conditions for the synthesis of benzimidazole $\mathbf{3 b a} \mathbf{a}^{\mathrm{a}}$

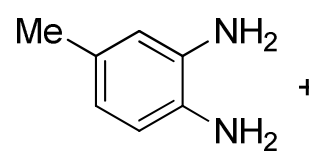

$1 \mathrm{~b}$

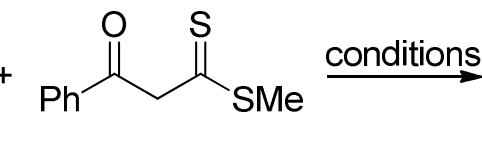

2a<smiles>Cc1ccc2[nH]c(-c3ccccc3)nc2c1</smiles>

3ba

\begin{tabular}{|c|c|c|c|c|c|}
\hline Entry & Catalyst (mol \%) & Solvent & Temp $\left({ }^{\circ} \mathrm{C}\right)$ & Time & Yield $^{\mathrm{b}}(\%)$ \\
\hline 1 & PTSA (10) & $-c$ & 90 & $15 \mathrm{~h}$ & 40 \\
\hline 2 & PTSA (10) & toluene $^{d}$ & 90 & $15 \mathrm{~h}$ & 40 \\
\hline 3 & PTSA (10) & toluene $^{d}$ & reflux & $12 \mathrm{~h}$ & 51 \\
\hline 4 & PTSA (10) & $-c$ & 120 & $10 \mathrm{~h}$ & 79 \\
\hline 5 & PTSA (10) & $-c$ & 140 & $8 \mathrm{~h}$ & $60^{e}$ \\
\hline 6 & PTSA (10) & $-{ }^{c}$ & 150 & $8 \mathrm{~h}$ & $49^{e}$ \\
\hline 7 & PTSA (5) & $-{ }^{c}$ & 120 & $12 \mathrm{~h}$ & 64 \\
\hline 8 & PTSA (20) & $-c$ & 120 & $10 \mathrm{~h}$ & 76 \\
\hline
\end{tabular}

${ }^{\mathrm{a}}$ All reactions were performed with $\mathbf{1 b}(0.5 \mathrm{mmol}), 2 \mathrm{2a}(0.5 \mathrm{mmol}) .{ }^{\mathrm{b}}$ Isolated pure yields. 'Solventless conditions (toluene, $0.2 \mathrm{~mL}) .{ }^{\mathrm{d}}$ toluene $(1.0 \mathrm{~mL}) .{ }^{\mathrm{e}}$ Complex TLC pattern.

Experiments probing the scope and generality of this new protocol under our optimized reaction conditions are summarized in Table 2. A broad range of $\beta$-oxodithioesters 2 , bearing $\mathrm{R}^{2}$ as aryl, hetaryl, and extended aromatic group were tolerated well. Various 1,2-phenylenediamines 1 with different $R^{1}$ such as $H, 4$ - 
$\mathrm{Me}, 4-\mathrm{Cl}$ and $4-\mathrm{Br}$ are found to be compatible well under standard reaction conditions. All reactions proceeded smoothly and afforded the corresponding product $\mathbf{3}$ in good to high yield. A range of $\beta$-oxodithioesters bearing $\mathrm{R}^{2}$ as aryl groups with electron-withdrawing substituents were well tolerated, and gave considerably higher yields than those with electron-donating groups (Table 2, 3ae, 3be vs. 3bc, 3dc). Moreover, halogen substitution on the $\mathrm{R}^{2}$ of dithioester did not disturb the reactivity, and the corresponding products were formed in high yields (Table 2, 3bd, 3cd). Importantly, dithioester $\mathbf{2}$ bearing a heteroaromatic moiety at $R^{2}$ was also found to be compatible providing high yield (76-85\%) of the product (3bf, 3df and $\mathbf{3 b g}$ ). After successful utilization of aromatic dithioesters, we next extended our study to extended aromatic dithioester such as 2naphthyl as $\mathrm{R}^{2}$ substituent, which was also tolerated well and enabled the desired product (3ch) in $79 \%$ yield. The spectral data of all the products are in accordance with the literature ${ }^{16-22}$ values.

Table 2. Substrate scope for the synthesis of benzimidazoles ${ }^{\mathrm{a}} \mathbf{3}$

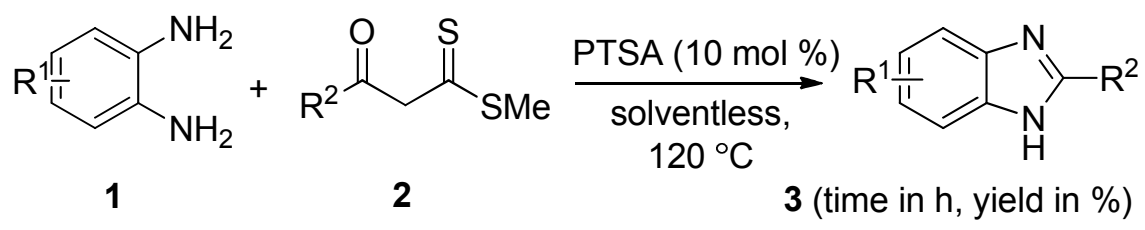<smiles>c1ccc(-c2nc3ccccc3[nH]2)cc1</smiles>

$\mathrm{Me}$<smiles>Cc1ccc(-c2nc3cc(C)ccc3[nH]2)cc1</smiles>

$3 b b(12,80)$<smiles>Cc1ccc2[nH]c(-c3ccc(Cl)cc3)nc2c1</smiles>

3bd $(9,80)$<smiles>Cc1ccc2[nH]c(-c3ccccc3)nc2c1</smiles>

3ba $(12,76)$<smiles>Clc1ccc2[nH]c(-c3ccccc3)nc2c1</smiles>

$\mathrm{Br}$<smiles>COc1ccc(-c2nc3cc(Br)ccc3[nH]2)cc1</smiles>

3 dc $(12,77)$<smiles>Clc1ccc(-c2nc3cc(Cl)ccc3[nH]2)cc1</smiles>

3cd $(8,84)$<smiles>FC(F)(F)c1ccc(-c2nc3ccccc3[nH]2)cc1</smiles>

3ae $(9,92)$<smiles>Cc1ccc2[nH]c(-c3ccc(C(F)(F)F)cc3)nc2c1</smiles>

3be $(8,88)$<smiles>Cc1ccc2[nH]c(-c3ccco3)nc2c1</smiles>

3bf $(11,78)$<smiles>Brc1ccc2[nH]c(-c3ccco3)nc2c1</smiles>

3 df $(10,85)$<smiles>Cc1ccc2[nH]c(-c3cccs3)nc2c1</smiles>

3 bg $(12,80)$

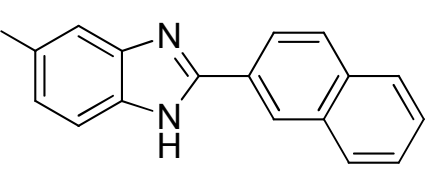

3 ch $(10,79)$

aUnless otherwise stated, reactions were performed with equimolar amount 1 and 2 (0.5 mmol each), PTSA (10 mol \%), toluene $(0.2 \mathrm{~mL}) .{ }^{\mathrm{b}}$ Isolated pure yield. 
A plausible reaction mechanism for the domino annulation of ortho-phenylenediamine with $\beta$ oxodithioester is shown in Scheme 2. The first step is suggested to be the Brønsted acid-catalyzed condensation of $\mathbf{1}$ with $\mathbf{2}$ to generate a ketimine intermediate $\mathbf{A}$. Ketiminium intermediate $\mathbf{A}$ undergoes $\mathbf{N}$ cyclization in the presence of $\mathrm{TsOH}_{\mathrm{H}} \mathrm{H}_{2} \mathrm{O}$ to form intermediate $\mathbf{B}$. The intermediate $\mathbf{B}$ undergoes selective $\mathrm{Csp}^{3}$ $\mathrm{Csp}^{3}$ bond cleavage ${ }^{42}$ to produce the desired benzimidazoles $\mathbf{3}$ with the elimination of one molecule of methyl dithioacetate.

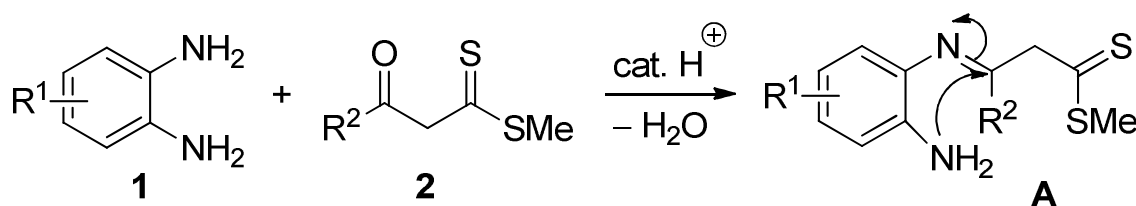

cat. $\stackrel{\oplus}{\mathrm{H}} \downarrow$ N-cyclization
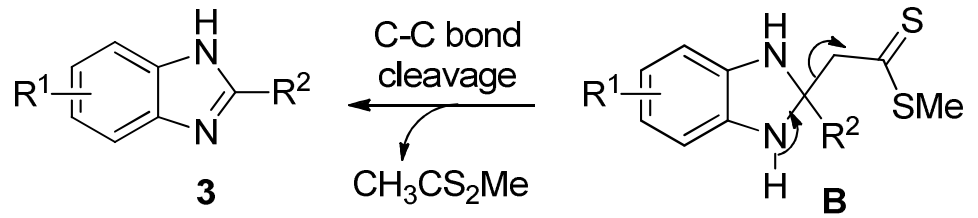

Scheme 2. Plausible mechanism for the formation of benzimidazoles 3.

\section{Conclusions}

In summary, we have devised an operationally simple and straightforward one-pot domino heteroannulation involving $\beta$-oxodithioesters and 1,2-phenylenediamines under metal-free solventless conditions for the first time. Under the optimal conditions, reactions proceeded smoothly to give diverse C-2 substituted benzimidazoles in good to high yields. It is noteworthy that the reaction tolerates a broad range of functional groups such as electron-rich, electron-neutral and electron-poor. Significantly, the presence of various groups makes these compounds excellent entrants as precursors for further synthetic renovations. We hope this clean and facile protocol would be valuable supplement to the traditional methods for the formation of benzimidazoles and could be of immense value for both synthetic and medicinal chemists.

\section{Experimental Section}

General. The commercially available 1,2-phenylendiamines were used as received without further purification. $\beta$-Oxo dithioesters 2 were prepared by the reported procedure. ${ }^{42}{ }^{1} \mathrm{H}$ and ${ }^{13} \mathrm{C} N M R$ spectra were recorded on NMR spectrometer operating at $500 \mathrm{MHz}$. Chemical shifts $(\delta)$ are given in parts per million (ppm) using the residual solvent peaks as reference relative to TMS. $J$ values are given in Hertz $(\mathrm{Hz})$. Chromatograms were visualized by fluorescence quenching with UV light at $254 \mathrm{~nm}$. Melting points are uncorrected.

General procedure for the synthesis of benzimidazoles (3) - An oven-dried $25 \mathrm{~mL}$ round bottom flask was charged with $0.5 \mathrm{mmol}$ of 1,2-phenylendiamines 1 , and $0.5 \mathrm{mmol}$ of $\beta$-oxodithioesters 2 . To this mixture 10 
mol \% of $p$-toluenesulfonic acid monohydrate was added followed by addition of $0.2 \mathrm{~mL}$ of toluene. The whole set-up was put on a pre-heated oil bath at $120{ }^{\circ} \mathrm{C}$ in an open air. After completion of the reaction (monitored through $\mathrm{TLC}$ ), the reaction mixture was quenched with water and extracted with ethyl acetate followed by washing with brine. The organic layer was dried over anhydrous $\mathrm{Na}_{2} \mathrm{SO}_{4}$ and concentrated under vacuum. The resultant residue was purified by column chromatography using silica gel as stationary phase and ethyl acetate-hexane (1:4) as eluent to afford the analytically pure desired products 3 . The spectral data of all the synthesized benzimidazoles are in agreement with the reported literature values.

2-Phenylbenzimidazole (3aa) - Obtained as yellow solid ( $0.08 \mathrm{~g}, 83 \%$ yield); $\mathrm{mp} 289-291{ }^{\circ} \mathrm{C}\left(\right.$ (lit $\left.^{26} 293{ }^{\circ} \mathrm{C}\right)$.

5-Methyl-2-phenylbenzimidazole (3ba) - Obtained as yellow solid $\left(0.08 \mathrm{~g}, 76 \%\right.$ yield); $\mathrm{mp} 236-238{ }^{\circ} \mathrm{C}\left(\mathrm{lit}{ }^{27}\right.$ 233-235 $\left.{ }^{\circ} \mathrm{C}\right)$.

5-Chloro-2-phenylbenzimidazole (3ca) - Obtained as yellow solid ( $0.09 \mathrm{~g}, 81 \%$ yield); mp $216-218^{\circ} \mathrm{C}\left(\mathrm{lit}^{28} 212-\right.$ $\left.214^{\circ} \mathrm{C}\right)$.

5-Methyl-2-(4-tolyl)benzimidazole (3bb) - Obtained as an off yellow solid (0.09 g, 80\% yield); mp $190-192{ }^{\circ} \mathrm{C}$ $\left(\right.$ lit $\left.^{17} 190-191^{\circ} \mathrm{C}\right)$.

5-Methyl-2-(4-methoxyphenyl)benzimidazole (3bc) - Obtained as yellow solid (0.08 g, 70\% yield); mp 145$147^{\circ} \mathrm{C}\left(\right.$ lit $\left.^{18} 142-144^{\circ} \mathrm{C}\right)$.

5-Bromo-2-(4-methoxyphenyl)benzimidazole (3dc) - Obtained as an off yellow solid (0.12 $\mathrm{g}, 77 \%$ yield); $\mathrm{mp}$ $192.0-194.0^{\circ} \mathrm{C}\left(\mathrm{lit}^{18} 194^{\circ} \mathrm{C}\right)$.

5-Methyl-2-(4-chlorophenyl)benzimidazole (3bd) - Obtained as yellow solid (0.10 g, 80\% yield); mp 222-224 ${ }^{\circ} \mathrm{C}\left(\right.$ lit $\left.^{18} 227-228^{\circ} \mathrm{C}\right)$.

5-Chloro-2-(4-chlorophenyl)benzimidazole (3cd) - Obtained as yellow solid $\left(0.11 \mathrm{~g}, 84 \%\right.$ yield); $\mathrm{mp} 224-226^{\circ} \mathrm{C}$ $\left(\right.$ lit $\left.^{18} 220-222^{\circ} \mathrm{C}\right)$.

2-(4-Trifluoromethylphenyl)benzimidazole (3ae) - Obtained as yellow solid $\left(0.12 \mathrm{~g}, 92 \%\right.$ yield); $\mathrm{mp} 280-282^{\circ} \mathrm{C}$ $\left(\right.$ lit $\left.^{28} 276-278^{\circ} \mathrm{C}\right)$.

5-Methyl-2-(4-trifluoromethylphenyl)benzimidazole (3be) - Obtained as yellow solid (0.12 g, $88 \%$ yield); mp $240-242^{\circ} \mathrm{C}\left(\right.$ (lit $\left.^{16} 242-244^{\circ} \mathrm{C}\right)$.

5-Methyl-2-(2-furyl)benzimidazole (3bf) - Obtained as yellow solid (0.08 g, 78\% yield); mp $192-194{ }^{\circ} \mathrm{C}\left(\right.$ lit ${ }^{19}$ $\left.187-188^{\circ} \mathrm{C}\right)$.

5-Bromo-2-(2-furyl)benzimidazole (3df) - Obtained as yellow solid (0.12 g, 85\% yield); mp $184-186{ }^{\circ} \mathrm{C}$ (lit ${ }^{20}$ $\left.180-181^{\circ} \mathrm{C}\right)$.

5-Methyl-2-(2-thienyl)benzimidazole (3bg) - Obtained as yellow solid $\left(0.09 \mathrm{~g}, 80 \%\right.$ yield); mp $232-234^{\circ} \mathrm{C}\left(\mathrm{lit}{ }^{21}\right.$ $\left.226-227^{\circ} \mathrm{C}\right)$.

5-Chloro-2-(2-naphthyl)benzimidazole (3ch) - Obtained as yellow solid (0.11 g, 79\% yield); $\mathrm{mp} 210-212{ }^{\circ} \mathrm{C}$ $\left(\right.$ lit $\left.^{22} 212-214^{\circ} \mathrm{C}\right)$.

\section{Acknowledgements}

We gratefully acknowledge the generous financial support of the Science and Engineering Research Board (Grant No. SERB/EMR/2015/002482) and the Council of Scientific and Industrial Research (Grant No. 02(0263)/16/EMR-II), New Delhi, India. A.S. and G.S. are thankful to the CSIR, and D.Y. is thankful to the UGC, New Delhi, for research fellowship. 


\section{References}

1. Welsch, M. E.; Snyder, S. A.; Stockwell, B. R. Curr. Opin. Chem. Biol. 2010, 14, 347. https://doi.org/10.1016/j.cbpa.2010.02.018

2. Hernandez-Luis, F.; Hernandez-Campos, A.; Castillo, R.; Navarrete-Vazquez, G.; Soria-Arteche, O.; Hernandez-Hernandez, M.; Yepez-Mulia, L. Eur. J. Med. Chem. 2010, 45, 3135. https://doi.org/10.1016/i.ejmech.2010.03.050

3. Saour, K.; Lafta, D. Anti-Cancer Agents Med. Chem. 2016, 16, 891 and references therein. https://doi.org/10.2174/1871520616666160204111637

4. Li, Y.-F.; Wang, G.-F.; He, P.-L.; Huang, W.-G.; Zhu, F.-H.; Gao, H.-Y.; Tang, W.; Luo, Y.; Feng, C.-L.; Shi, L.-P.; Ren, Y.-D.; Lu, W.; Zuo, J.-P. J. Med. Chem. 2006, 49, 4790. https://doi.org/10.1021/jm060330f

5. Chassaing, C.; Berger, M.; Heckeroth, A.; Ilg, T.; Jaeger, M.; Kern, C.; Schmid, K.; Uphoff, M. J. Med. Chem. 2008, 51, 1111.

6. Mavrova, A. T.; Yancheva, D.; Anastassova, N.; Anichina, K.; Zvezdanovic, J.; Djordjevic, A.; Markovic, D.; Smelcerovic, A. Bioorg. Med. Chem. 2015, 23, 6317.

https://doi.org/10.1016/i.bmc.2015.08.029

7. Cereda, E.; Turconi, M.; Ezhaya, A.; Bellora, E.; Brambilla, A.; Pagani, F.; Donetti, A. Eur. J. Med. Chem. 1987, 22, 527.

https://doi.org/10.1016/0223-5234(87)90293-5

8. Wang, J.-L.; Zhang, J.; Zhou, Z.-M.; Li, Z.-H.; Xue, W.-Z.; Xu, D.; Hao, L.-P.; Han, X.-F.; Fei, F.; Liu, T.; Liang, A.-H. Eur. J. Med. Chem. 2012, 49, 183. https://doi.org/10.1016/j.ejmech.2012.01.009

9. Park, B.; Awasthi, D.; Chowdhury, S. R.; Melief, E. H.; Kumar, K.; Knudson, S. E.; Slayden, R. A.; Ojima, I. Bioorg. Med. Chem. 2014, 22, 2602.

https://doi.org/10.1016/i.bmc.2014.03.035

10. Oren, I. Y.; Yalcin, Y.; Sener, E. A.; Ucarturk, N. Eur. J. Med. Chem. 2004, 39, 291. https://doi.org/10.1016/i.ejmech.2003.11.014

11. Asensio, J. A.; Gomez-Romero, P. Fuel Cells 2005, 5, 336.

https://doi.org/10.1002/fuce.200400081

12. Singh, N.; Jang, D. O. Org. Lett. 2007, 9, 1991.

https://doi.org/10.1021/ol070592r

13. Ooyama, Y.; Nakamura, T.; Yoshida, K. New J. Chem. 2005, 29, 447.

https://doi.org/10.1039/b410311d

14. Preston, P. N. Chem. Rev. 1974, 74, 279.

https://doi.org/10.1021/cr60289a001

15. Horton, D. A.; Bourne, G. T.; Smythe, M. L. Chem. Rev. 2003, 103, 893. https://doi.org/10.1021/cr020033s

16. Yuan, H.; Chen, Y.; Song, J.; Chen, C.; Chen, B. Chin. J. Chem. 2013, 31, 1247. https://doi.org/10.1002/cjoc.201300429

17. Bahrami, K.; Khodaei, M. M.; Kavianinia, I. Synthesis 2007, 4, 547. https://doi.org/10.1055/s-2007-965878

18. Dinparasta, L.; Valizadehb, H.; Bahadoric, M. B.; Soltanid, S.; Asgharie, B.; Rashidi, M.-R. J. Mol. Struct. 2016, 1114, 84. 
https://doi.org/10.1016/i.molstruc.2016.02.005

19. Diao, X.; Wang, Y.; Jiang, Y.; Ma, D. J. Org. Chem. 2009, 74, 7974.

https://doi.org/10.1021/jo9017183

20. Bistocchi, G. A.; Meo, G. D.; Pedini, M.; Ricci, A.; Pitzurra, M.; Cavallo, R.; Sposini, T.; Jacquignon, P.

Farmaco Sci. 1982, 37, 597.

21. Kumar, V.; Khandare, D. G.; Chatterjee, A.; Banerjee, M. Tetrahedron Lett. 2013, 54, 5505. https://doi.org/10.1016/j.tetlet.2013.07.147

22. Blaszczak-Swiatkiewicz, K.; Mikiciuk-Olasik, E. Acta Pol. Pharm. 2013, 70, 451.

23. Kovvuri, J.; Nagaraju, B.; Kamal, A.; Srivastava, A. K. ACS Comb. Sci. 2016, 18, 644 and references therein. https://doi.org/10.1021/acscombsci.6b00107

24. Baars, H.; Beyer, A.; Kohlhepp, S. V.; Bolm, C. Org. Lett. 2014, 16, 536.

https://doi.org/10.1021/ol403414v

25. Dudd, L. M.; Venardou, E.; Garcia-Verdugo, E.; Licence, P.; Blake, A. J.; Wilson, C.; Poliakoff, M. Green Chem. 2003, 5, 187.

https://doi.org/10.1039/b212394k

26. Mahesh, D.; Sadhu, P.; Punniyamurthy, T. J. Org. Chem. 2015, 80, 1644.

https://doi.org/10.1021/j0502574u

27. Nguyen, T. B.; Ermolenko, L.; Dean, W. A.; Al-Mourabit, A. Org. Lett. 2012, 14, 5948. https://doi.org/10.1021/ol302856w

28. Nguyen, T. B.; Ermolenko, L.; Al-Mourabit, A. Synthesis 2015, 47, 1741. https://doi.org/10.1055/s-0034-1380134

29. Nguyen, T. B.; Le Bescont, J.; Ermolenko, L.; Al-Mourabit, A. Org. Lett. 2013, 15, 6218. https://doi.org/10.1021/ol403064z

30. Mayo, M. S.; Yu, X.; Zhou, X.; Feng, X.; Yamamoto, Y.; Bao, M. Org. Lett. 2014, 16, 764. https://doi.org/10.1021/ol403475v

31. Bastug, G.; Eviolitte, C.; Markó, I. E. Org. Lett. 2012, 14, 3502.

https://doi.org/10.1021/ol301472a

32. Tandon, V. K.; Kumar, M. Tetrahedron Lett. 2004, 45, 4185.

https://doi.org/10.1016/j.tetlet.2004.03.117

33. Singh, M. S.; Nandi, G. C.; Chanda, T. RSC Adv. 2013, 3, 14183.

https://doi.org/10.1039/c3ra41094c

34. Chowdhury, S.; Chanda, T.; Koley, S.; Anand, N.; Singh, M. S. Org. Lett. 2014, 16, 5536. https://doi.org/10.1021/ol502850h

35. Ramulu, B. J.; Nagaraju, A.; Chowdhury, S.; Koley, S.; Singh, M. S. Adv. Synth. Catal. 2015, 357, 530. https://doi.org/10.1002/adsc.201400828

36. Koley, S.; Chanda, T.; Ramulu, B. J.; Chowdhury, S.; Anand, N.; Singh, M.S. Adv. Synth. Catal. 2016, 358, 1195.

https://doi.org/10.1002/adsc.201500962

37. Koley, S.; Chanda, T.; Samai, S.; Singh, M. S. J. Org. Chem. 2016, 81, 11594.

https://doi.org/10.1021/acs.joc.6b01802

38. Shukla, G.; Srivastava, A.; Singh, M. S. Org. Lett. 2016, 18, 2451.

https://doi.org/10.1021/acs.orglett.6b00997

39. Ramulu, B. J.; Koley, S.; Singh, M. S. Org. Biomol. Chem. 2016, 14, 434.

https://doi.org/10.1039/C5OB02081F 
40. Nagaraju, A.; Ramulu, B. J.; Shukla, G.; Srivastava, A.; Verma, G. K.; Singh, M. S. ARKIVOC 2016, (ii), 42. http://dx.doi.org/10.3998/ark.5550190.p009.179

41. Srivastava, A.; Shukla, G.; Singh, M. S. Tetrahedron 2017, 73, 879.

https://doi.org/10.1016/i.tet.2016.12.073

42. Samuel, R.; Asokan, C. V.; Suma, S.; Chandran, P.; Retnamma, S.; Anabha, E. R. Tetrahedron Lett. 2007, $48,8376$.

https://doi.org/10.1016/i.tetlet.2007.09.076 